\title{
Microbial Treatment of Lateritic Ni-ore for Iron Beneficiation and Their Characterization
}

\author{
N. $\operatorname{Pradhan}^{1}$, R. R. Nayak ${ }^{2}$, D. K. Mishra ${ }^{1}$, E. Priyadarshini ${ }^{1}$, L. B. Sukla ${ }^{1, *}$, B. K. Mishra ${ }^{1}$ \\ ${ }^{1}$ Institute of Minerals and Materials Technology, Council of Scientific \& Industrial Research (CSIR), Bhubaneswar, 751013, India \\ ${ }^{2}$ Indian Institute of Chemical Technology, Council of Scientific \& Industrial Research (CSIR), Hyderabad, 500 007, India
}

\begin{abstract}
This study aims at studying effect of anaerobic dissimilatory iron (III) reducing bacterial consortium on different phases of iron present in lateritic nickel ore. Such conversion in lateritic nickel ore are helpful in better recovery of sorbed metal values like $\mathrm{Ni}$ and $\mathrm{Co}$ by subsequent bioleaching or acid leaching. Here properties of thermally and microbially reduced lateritic nickel ore are compared vis-à-v is orig inal ore. An anaerobic dissimilatory iron (III) reducing bacterial consortium capable of using glucose as carbon source and lateritic nickel ore as terminal electron acceptor was used for microbial reduction of ore under anaerobic condition. Microbial reduction changes the initial light brown colour of the lateritic nickel ore to dark brown. The change in colour is due to the conversion of goethite to magnetite, which is confirmed from the XRD pattern. The FTIR spectra and the UV-Visible spectra support the presence both goethite and hematite. The study shows that changes in phases brought about by microbial treatment are different than those by thermal treatment. The carrier mediated exchange interaction between $\mathrm{Fe}^{2+}$ and $\mathrm{Fe}^{3+}$ ions in lateritic nickel ore sample treated with IRB consortium is responsible for higher ferromagnetic ordering. The thermal reduction of the same sample showed lowering of ferro magnetic ordering due to the decreasing percentage of $\mathrm{Fe}^{2+}$ and $\mathrm{Fe}^{3+}$ ions.
\end{abstract}

Keywords Iron Reducing Bacteria, Lateritic Ore, Goethite, Magnetite, Magnetic Properties

\section{Introduction}

In lateritic nickel ore, nickel is associated with iron phase where as cobalt is associated with manganese phase[1]. Natural Fe(III) oxides are high in surface area and are reactive[2]. Fe(III) oxides adsorb a wide range of metal cations and anions by complexation to surface hydroxyl groups[3]. Nickel lateritic ore of Sukinda, Orissa, contains $0.8 \% \mathrm{Ni}$ and $0.049 \%$ Co which makes them the only nickel deposit in India. More focus had been given by IMMT Bhubaneswar on this material for extraction of nickel and cobalt[4-7]. However, thermal activation or thermal reduction of ore is required for better recovery of metal values[8]. Heating of ore resulted in conversion of goethite to hematite, which was responsible for releasing nickel from $\mathrm{Fe}$ (II) lattice and resulted in better recovery[7]. This type of reduction is not cost effective in terms of energy consumption and may not be employed for large scale operations. Hence, it is desirable to have an alternative ecofriendly and low cost method, which makes the subsequent metal extraction more feasible.

Ferric iron oxides are widespread in anoxic aqueous environment and have been reported to act aselectron sink during biodegradation of various natural and xenobiotic

* Corresponding author:

lbsukla@immt.res.in (L.B. Sukla)

Published online at http://journal.sapub.org/env

Copyright (C) 2012 Scientific \& Academic Publishing. All Rights Reserved compounds[9-11].

Microbial Fe (III) reduction results in the generation of several important $\mathrm{Fe}(\mathrm{II})$-containing minerals in sedimentary environments, including magnetite $\mathrm{Fe}(\mathrm{II}) \mathrm{Fe}(\mathrm{III})_{2} \mathrm{O}_{4}$, which is a magnetic mineral. Magnetite formation during dissimilatory $\mathrm{Fe}(\mathrm{III})$ reduction is reported for different pure cultures of bacteria[12] as well as for Fe(III)-reducing enrichment consortium[13]. Mic robial dissimilatory Fe(III) reduction plays an important role in the geochemical cycling of iron and organic matter in anoxic ecological system[14]. Iron-reducing microbes generally belong to the genera Shewanella, Geobacter, Geovibrio, Desulfobulbus etc [15-17]. If bacterial reduction method is successful, cost intensive method of ore roasting process can be eliminated. Such 'dissimilatory' processes have opened up new and fascinating areas of research with potentially exciting practical applications.

Applying a biological approach to address this problem, we investigated the use of naturally occurring iron reducing bacteria for the reduction of lateritic nickel ore (iron phase) in a low cost ecofriendly way.

\section{Materials and Methods}

\subsection{Lateritic Nickel Ore}

Lateritic Nickel ore was procured from Sukinda mines of Orissa Mining Corporation (OMC), India. The sample was a 
low grade lateritic ore which contains about $0.8 \% \mathrm{Ni}$, $0.049 \% \mathrm{Co}, 1.92 \% \mathrm{Cr}, 0.32 \% \mathrm{Mn}$, and $50.2 \% \mathrm{Fe}$. For the experimental purpose the ore samples were heated at $600{ }^{\circ} \mathrm{C}$ for 5 hours to convert the goethite to hematite which is reported to aid the release of the nickel bound to goethite matrix. Thermal activation of the lateritic nickel ore has significant influence on nickel and cobalt recovery[18]. The thermal activation changes the mineral structure and brings about mineral phase transformation by dehydroxylation of the goethite[19].

\subsection{Microorganisms}

Soil sediment from a wetland sites around Bhubaneswar, Orissa, India was used as source of iron reducing bacteria. After collecting, these were immediately transferred to anaerobic vials and taken to the laboratory for subsequent enrich ment of $\mathrm{Fe}$ (III) reducing bacteria.

\subsection{Enrichment and Isolation of Fe(III)-Reducers}

One gram of sediment was transferred to a vial containing $10 \mathrm{ml}$ of anaerobic saline solution. These vials were thoroughly mixed, allowed to settle for 10 minutes and then $5 \mathrm{ml}$ of liquid was used to inoculate $100 \mathrm{ml}$ selective alkaline anaerobic iron reducing medium in volumetric flasks. This medium contains Nickel ore $1.0 \mathrm{~g} / \mathrm{l} ; \mathrm{K}_{2} \mathrm{HPO}_{4} 3.0 \mathrm{~g} / \mathrm{l}$; $\mathrm{KH}_{2} \mathrm{PO}_{4} 0.8 \mathrm{~g} / \mathrm{l} ; \mathrm{KCl} 0.2 \mathrm{~g} / \mathrm{l} ; \mathrm{NH}_{4} \mathrm{Cl} 1.0 \mathrm{~g} / \mathrm{l} ; \mathrm{MgCl}_{2} 0.2 \mathrm{~g} / \mathrm{l} ;$ $\mathrm{CaCL}_{2} 0.1 \mathrm{~g} / \mathrm{l}$; Yeast extract $0.05 \mathrm{~g} / \mathrm{l}$; mixture of vitamins and trace minerals solution $1 \%(\mathrm{v} / \mathrm{v})$ and $10 \mathrm{mM}$ sodium acetate $\left(\mathrm{C}_{2} \mathrm{H}_{3} \mathrm{O}_{2} \mathrm{Na}\right)$. $\mathrm{pH}$ of the media was adjusted to 7.2 with the help of $1 \mathrm{~N} \mathrm{NaOH}$. Liquid surface was covered with paraffin oil to make the system anaerobic. The flasks were incubated at $30^{\circ} \mathrm{C}$ for several days under dark condition. The enrichment procedure was repeated four times with the transfer of $10 \mathrm{ml}$ of culture as inoculum into the fresh medium. The enrich ment cultures after five successive transfers were used as inoculum for lateritic nickel ore reduction experiments.

\subsection{Treatment of Lateritic Nickel Ore with IRB Consortium}

Lateritic nickel ore was treated with well enriched Fe(III) reducing bacterial consortium in an anaerobic, alkaline medium at $2 \%$ pulp density and kept at $30^{\circ} \mathrm{C}$ for 7 days under dark condition. Simultaneously control experiments without any bacterial solution were also run. After treatment, the treated lateritic nickel ore was filtered and air dried. In a similar set of experiments the heated lateritic nickel ore was taken instead of the original ore. The reduction of highly insoluble $\mathrm{Fe}(\mathrm{III})$ oxides resulted in dissolution of soluble $\mathrm{Fe}(\mathrm{II})$ ions in the growth medium. This soluble ferrous-ion was determined by titration[20].

Samples are designated as $\mathrm{O} 1$ for lateritic ore and $\mathrm{O} 2$ for lateritic nickel ore sample treated with IRB consortium. Similarly R1 for heated lateritic nickel ore sample and R2 for heated lateritic nickel ore sample treated with IRB consortium.

\subsection{Analysis}

$\mathrm{X}$-ray diffraction analysis was carried out by an X-ray powder diffracto meter (Philips X'pert Pro, Panalytical) using Mo $\mathrm{K} \alpha(\lambda=0.7107 \AA)$ as X-ray source and a programmable divergence slit. The voltage and current of the $x$-ray source were $40 \mathrm{kV}$ and $20 \mathrm{~mA}$, respectively. UV-visible absorption spectra of all the samples were taken with a Varian Cary 100 spectrophotometer in the region $200-800$ $\mathrm{nm}$ to determine the mineral species through absorption band gap. Fourier transform infrared spectra were recorded on a FTIR system (spectrum GX model supplied by Perkin Elmer instrument, USA). The spectra were recorded from 400 to $4000 \mathrm{~cm}^{-1}$. The surface morphology was observed in a Field Emission Scanning Electron Microscope (Zeiss Supra 55, observation conditions $\mathrm{V}-20 \mathrm{kV}, \mathrm{I}-0.6 \mathrm{nA}$ ) after coating the surface with gold to reduce the charging effect. Microscopic image of the IRB consortium was taken in Nikon 80i optical microscope. The room temperature magnetic hysteresis studies of samples were carried out using Vibrating Sample Magnetometer (VSM) (Model: Lakeshore 7410) at an applied magnetic field of $2 \mathrm{~T}$.

\section{Results and Discussion}

Dissimilatory iron reducing bacterial consortium was enriched in an anaerobic mineral salt medium containing lateritic nickel ore composed of insoluble ferric iron in the form of goethite. The medium contained acetate ions as carbon source (electron donor) and ammoniu m chloride as nitrogen source for bacterial metabolis $m$. In this system, bacteria oxidizes carbon source and the released electron pass through a series of electron carrier molecules to generate ATP, the biochemical energy needed for bacterial metabolis $\mathrm{m}$. The ultimate electron acceptor or electron sink in absence of oxygen is the Fe(III) present in goethite. After accepting the electron, Fe(III) gets reduced to Fe(II) which results in phase change. Due to the phase changes, original light brown colour of the lateritic nickel ore transform to dark brown. No such change was observed in the control experiment.

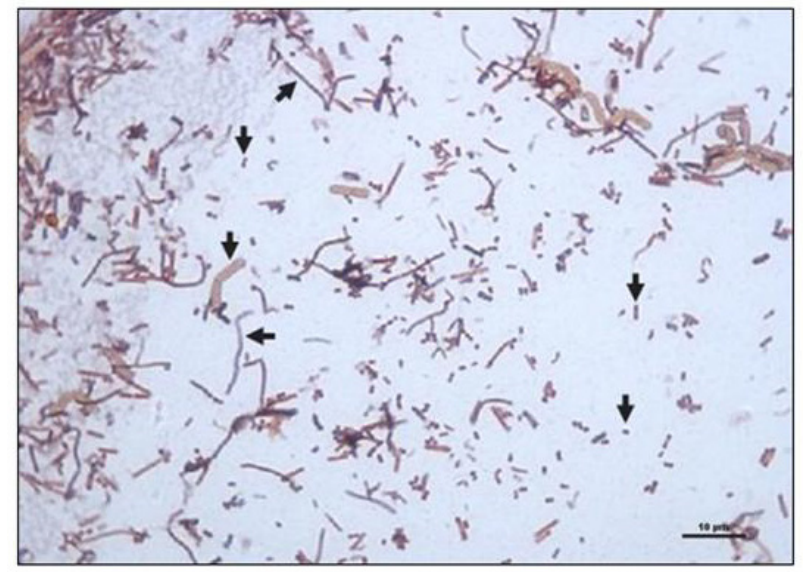

Figure 1. Gram staining of iron reducing bacterial consortia 
Gram staining of IRB consortium demonstrates the presence of both gram positive and negative bacteria of different morphology. An optical microscopic image shows 6 morphologically different species (Figure 1). Scanning electron micrograph show long curve rod shaped bacteria in close association with ore particles (Figure 2). Bacteria of length up to $6 \mu \mathrm{m}$ were observed. The bio-film formations around the ore particles were evident. So me granular material could be seen around bacteria which may be extracellu lar magnetite deposition (encircled in the Figure 2). Similar depositions had been reported by Hansel[21]

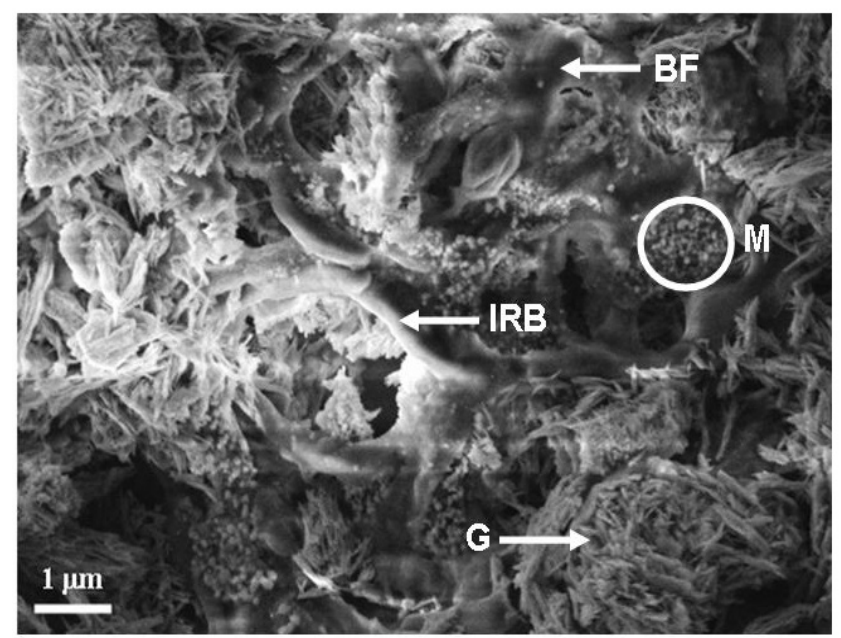

Figure 2. SEM image showing needle shaped goethite particles $(\mathrm{G})$ bacterial bio-film (BF), Iron reducing bacteria (IRB) and granular magnet ite particles $(\mathrm{M})$ in close association with ore particles

The anaerobic IRB consortium grew well in the media with lateritic nickel ore as only electron acceptor and convert $\mathrm{Fe}(\mathrm{III})$ to $\mathrm{Fe}$ (II) as evident by release of ferrous ion in the medium during growth of consortia (Figure 3). The ferrous ions formed remain adsorbed to the solid ore particles. These $\mathrm{Fe}(\mathrm{II})$ ions were detectable only after washing the ore material with $0.1 \mathrm{~N} \mathrm{HCl}$. In itially $\mathrm{pH}$ decreases to 6 during first 15 days of incubation but after that it remains constant at around 7.4 (Figure 3).

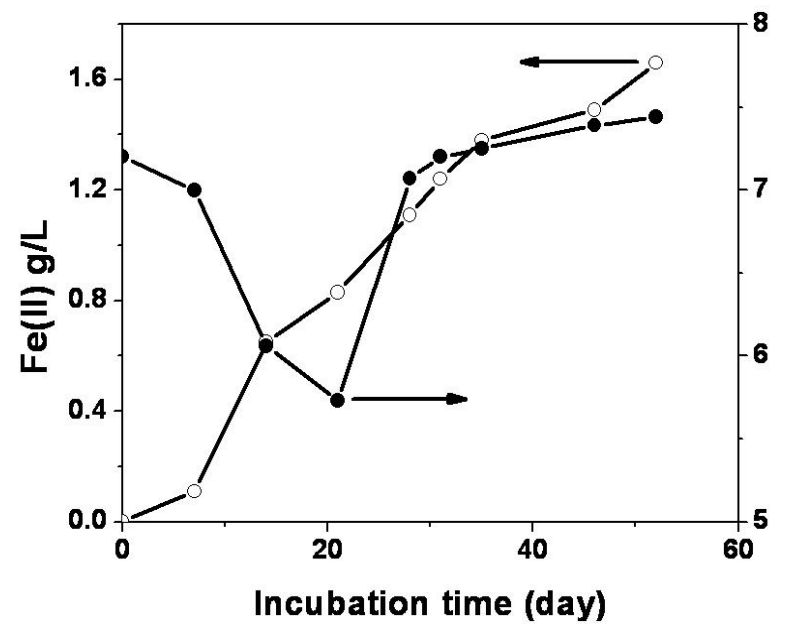

Figure 3. Release of $\mathrm{Fe}$ (II) ion in medium and change in $\mathrm{pH}$ during growth
The X-ray diffraction peak is shown in Figure. 4. The XRD pattern of $\mathrm{O} 1$ shows the Bragg reflection peaks of goethite as well as hematite. The intensity of hematite peaks increased as the ore was treated with bacterial consortia in anaerobic condition. A small percentage of magnetite peaks was observed in the $\mathrm{O} 2$. The bacteria acts as a reducing agent and converts the goethite to hematite and magnetite. Such peaks were lower in the intensity in $\mathrm{O} 1$. The intensity ratio of hematite to goethite is in increased ratio in comparis on to $\mathrm{O}$. However the presence of hematite, magnetite rep resents that the material is an admixture of two iron states i.e. Fe (II) and $\mathrm{Fe}$ (III). When the ore $\mathrm{O} 1$ is annealed at $600{ }^{\circ} \mathrm{C}$, the goethite phase converts to protohematite with a small percentage of goethite leaving behind. It is already reported in the literature that at around $250{ }^{\circ} \mathrm{C}$, goethite converts to protohematite and at or above $800^{\circ} \mathrm{C}$, it converts to hematite[22]. As our annealing temperature was $600{ }^{\circ} \mathrm{C}$, there is maximum possibility of conversion of goethite to protohematite, which is clearly reflected in the XRD pattern of R1. But the bacteria treated annealed ore (R2) showed improved crystalline peaks of hematite and reduction in the intensity of goethite peaks. The small amount of goethite present in R2 couldn't be established within the instrumental limitation. This feature is further well supported from the UV-Vis ible and FTIR studies.

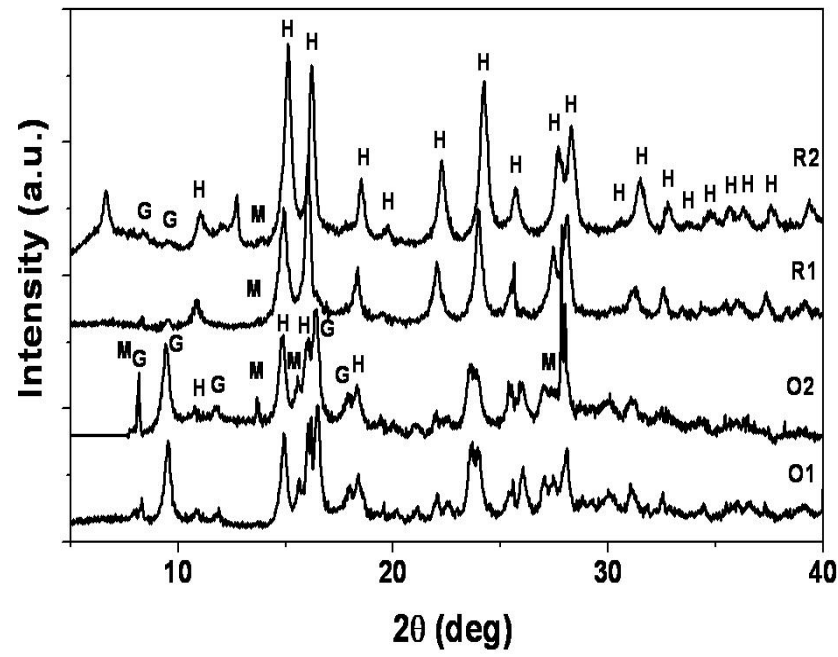

Figure 4. XRD pattern of original nickel laterite ore and IRB treated samples. H: Hemat ite $\left(\mathrm{Fe}_{2} \mathrm{O}_{3}\right)$; G: Goethite $(\mathrm{FeOOH})$; M: Magnet ite $\left(\mathrm{Fe}_{3} \mathrm{O}_{4}\right)$

In UV-Visible spectra three absorption bands were observed at the wavelength of 367,483 and $678 \mathrm{~nm}$ for $\mathbf{O 1}$ and O2 (Figure 5). The higher wavelength $(678 \mathrm{~nm}$ ) and lower wavelength $(367 \mathrm{~nm})$ is attributed to the optical absorptions band of goethite where as the optical band gap at $483 \mathrm{~nm}$ is attributed to the absorption bands of goethite and hematite. In R1 and R2, the optical absorption band is observed at 529 $\mathrm{nm}$ which completely reflects the presence of hematite only and a sharp absorption band is observed at $367 \mathrm{~nm}$, attributed to goethite. Even in R2, presence of goethite was not observed in XRD due to instrumental limitation, but was confirmed from the UV-Visible spectra. It is well known that the band gap of goethite is higher than the band gap of hematite, 
which is well reflected from the shifting of bands in the spectrum.

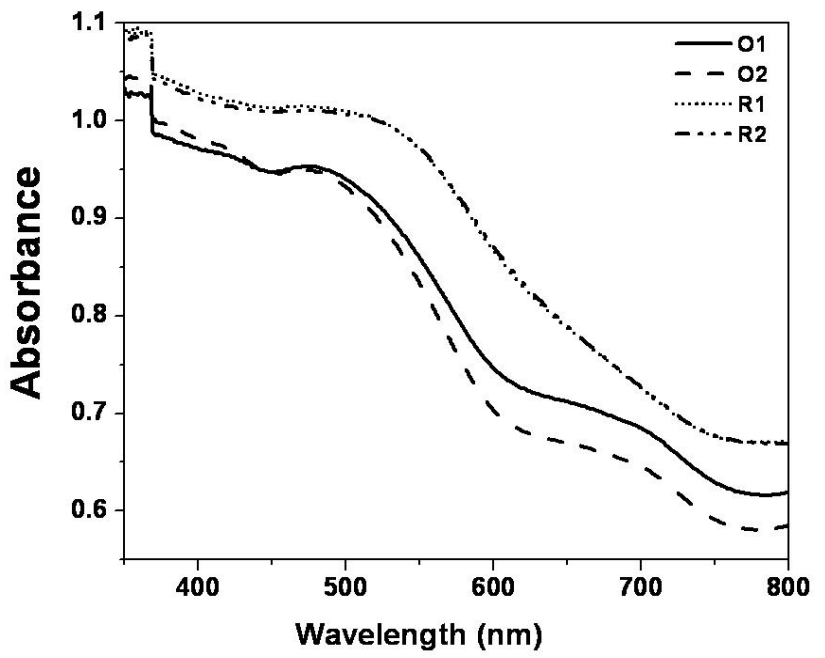

Figure 5. UV-visible spectrum of original nickel laterite ore and IRB treated samples

From the literature, hematite has six active IR modes of active IR whereas goethite has 36 modes Fe-O vibration modes and 12 hydroxyl group modes of vibration. Well distinct FTIR modes of vibration for goethite and hematite were observed in $\mathrm{O} 1$ and $\mathrm{O} 2$ (Table 1), whereas the FTIR peak observed in R1 and R2 are attributed to the hematite. Only the peak $465 \mathrm{~cm}^{-1}$ is attributing to the goethite. So me peaks are attributed to the hydroxyl group modes of vibration that may be due to the surface contamination of water during experiment done at open at mosphere. Our well studied XRD, UV-Visible and FTIR analysis predicts that $\mathrm{O} 1$ and $\mathrm{O} 2$ is a composites of both goethite and hematite whereas $\mathrm{R} 1$ is a hematite with small percentages of goethite. R2 is completely a hematite.

Table 1. FTIR wavenumbers and peak assignment for all the samples

\begin{tabular}{|c|c|c|c|c|}
\hline \multicolumn{3}{|c|}{ Sample Specification } & \multirow{2}{*}{$\begin{array}{c}\text { Iron phase } \\
\text { Assignment*[2] }\end{array}$} \\
\cline { 1 - 3 } O1 & O2 & R1 & R2 & H \\
\cline { 1 - 2 } Wavenumber $\left(\mathrm{cm}^{-1}\right)$ & $\mathrm{G}, \mathrm{H}$ \\
449 & 449 & 449 & 449 & $\mathrm{H}$ \\
466 & 465 & 465 & 465 & $\mathrm{H}$ \\
& & 512 & 515 & $\mathrm{Fe}-\mathrm{OH}$ \\
685 & 680 & 715 & 718 & $\mathrm{Fe}-\mathrm{OH}$ \\
822 & 822 & & & \\
931 & 931 & &
\end{tabular}

* where H: Hematite; G: Goethite

The magnetic hysteresis recorded for all the samples are shown in Figure 6. The $\mathrm{MH}$ loop recorded for the $\mathrm{O} 1$ shows a small loop with remnant magnetization $\left(\mathrm{M}_{\mathrm{r}}\right)$ of $0.083 \mathrm{emu} / \mathrm{g}$ and coerecivity $\left(\mathrm{H}_{\mathrm{c}}\right)$ of $311 \mathrm{Oe}$. No saturation magnetization $\left(M_{s}\right)$ has been observed even at the applied field of 20000 Oe, whereas the MH loop recorded for R1 shows lower remnant magnetization of $0.021 \mathrm{emu} / \mathrm{g}$ and coerecivity of $293 \mathrm{Oe}$. This may be possible due to the transformation of goethite to hematite at $600^{\circ} \mathrm{C}$. While $\mathrm{O} 2$ shows higher saturation magnetization value of $1.5 \mathrm{emu} / \mathrm{g}$ with remnant magnetization value of $0.328 \mathrm{emu} / \mathrm{g}$ and coercivity of $235 \mathrm{Oe}$. This observation provides evidence that the bacteria acts as a reducing agent to convert goethite to hemat ite in the solution. It is well known that hematite is weakly ferromagnetic at room temperature. R2 shows lower magnetization value of $0.876 \mathrm{emu} / \mathrm{g}$ with remnant magnetization of $0.185 \mathrm{emu} / \mathrm{g}$ and coercivity of 266 Oe than that of $\mathrm{O} 2$. Here the bacteria only act as reducing agent for converting goethite to hematite. Hence the percentage of goethite becomes less in comparison of the hematite. The $\mathrm{M}_{\mathrm{s}}, \mathrm{M}_{\mathrm{r}}$ and $\mathrm{H}_{\mathrm{c}}$ value for all the samples are given in Table 2 .

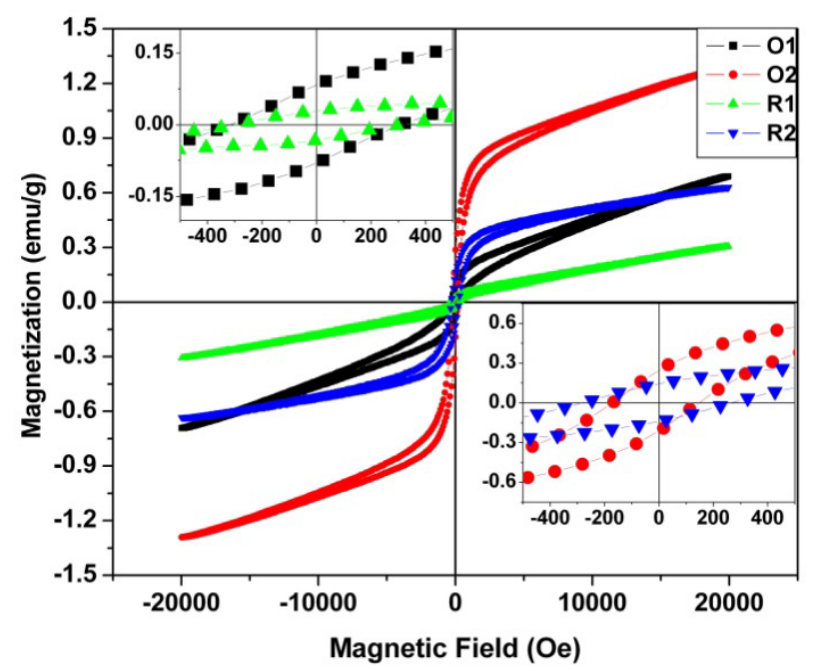

Figure 6. Hysteresis loop curve for all the samples

Table 2. Saturation magnetization, remnant magnetization and coercive field of all the samples

\begin{tabular}{|c|c|c|c|c|}
\hline Sl. No & Samples & $\mathrm{M}_{\mathrm{s}}$ in emu/g & $\mathrm{M}_{\mathrm{r}}$ in emu/g & $\mathrm{H}_{\mathrm{c}}$ in Oe \\
\hline 1 & O1 & --- & 0.083 & 311 \\
\hline 2 & $\mathrm{R} 1$ & --- & 0.021 & 293 \\
\hline 3 & $\mathrm{O} 2$ & 1.54 & 0.328 & 235 \\
\hline 4 & $\mathrm{R} 2$ & 0.876 & 0.185 & 266 \\
\hline
\end{tabular}

Goethite and hematite have iron in $3+$ valence state, whereas valence state of iron in magnetite is in-between $2+$ and $3+$. So a well admixture of $\mathrm{Fe}$ (II) and $\mathrm{Fe}$ (III) in a material results in a ferromagnetic coupling interaction between the iron ions, which enhances the ferro magnetic ordering and can be explained on the basis of RKKY exchange interaction. As observed in $\mathrm{O} 2, \mathrm{Fe}$ exists in the multiple valence state of $2+$ and $3+$, hence there is a strong possibility of carrier mediated exchange interaction in between $\mathrm{Fe}^{3+}$ and $\mathrm{Fe}^{2+}$ ions via oxygen. Such type of exchange interaction is known as double exchange interaction[23, 24] because the conduction electron transfers from one $\mathrm{Fe}$ ions to another $\mathrm{Fe}$ ions through oxygen. Such type of carrier mediated exchange interaction imp roves the ferro magnetic ordering in the system and hence enhances the magnetization. However, only hematite exists in R2 with a very small percentage of magnetite. So the short range exchange interaction between $\mathrm{Fe}(\mathrm{III})$ and $\mathrm{Fe}(\mathrm{III})$ is dominating over the long range $\mathrm{Fe}(\mathrm{II})$ and $\mathrm{Fe}(\mathrm{III})$ exchange interaction, thus lowering the saturation magnetization in $\mathrm{R} 2$ in comparis on to $\mathrm{O} 2$. Therefore, the competing exchange interaction between short range ordered 
anti-ferromagnetic coupling in between similar type of $\mathrm{Fe}$ ions and long range ordered FM coupling between Fe(II) and $\mathrm{Fe}(\mathrm{III})$ ions reduces the saturation magnetization value. This is clearly evidenced from the $\mathrm{MH}$ loop of Figure 6.

\section{Conclusions}

Lateritic nickel ore when subjected to treatment with anaerobic dissimilatory iron (III) reducing bacterial consortium show phase changes in iron minerals. Comparison of properties of thermally and mic robially reduced lateritic ore vis a vis original o re show that changes in phases brought about by microbial reduction were different than those by thermal reduction. Magnetite formation was more prominent in case of mic robial treatment of orig inal o re than roasted ore which is well pictured in the XRD pattern. Roasting leads to the formation of hematite. The carrier mediated exchange interaction between $\mathrm{Fe}$ (II) and $\mathrm{Fe}$ (III) ions in laterite nickel ore sample treated with IRB consortium is responsible for higher ferromagnetic ordering.IRB consortia treated ore showed higher saturation magnetization value of $1.5 \mathrm{emu} / \mathrm{g}$ with remnant magnetization value of $0.328 \mathrm{emu} / \mathrm{g}$ and coercivity of 235 Oe. The thermal activation of the same sample shows lowering in ferromagnetic ordering due to the decreasing percentage of $\mathrm{Fe}(\mathrm{II})$ and $\mathrm{Fe}(\mathrm{III})$ ions. Thermally activated ore was less amenable to further phase changes by mic robial treatment. From this study we conclude that naturally occurring iron reducing bacterial consortia could be for better recovery of metal values in a cost effective and eco-friendly way.

\section{ACKNOWLEDGEMENTS}

SEM and XRD measurements were carried out by $\mathrm{Mr}$. Debadutta Sahoo and Mrs. Swagatika Mohanty, to who m our sincere thanks are due. DKM would like to express his sincere thanks to Council of Scientific and Industrial Research (CSIR), India for fellowship under CSIR quick hire scheme. EP would like to express her sincere thanks to Department of Science and Technology, India for 'Inspire' fellowship.

\section{REFERENCES}

[1] Sukla L.B., Kar R.N., Panchanadikar V.V., Choudhury S., Mishra R.K., "Bioleaching of lateritic nickel ore using Penicillium species", Trans. Indian Inst. Met. vol. 48,pp.103-106, 1995.

[2] Cornell R.M., Schwertmann U., "The Iron oxides: Structure, Properties, Reactions, Occurrences and Uses", WILEY-VCH $\mathrm{GmbH} \& \mathrm{Co}$. KGaA, Weinheim.

[3] Schindler P.W., Stumm W., "The surface chemistry of oxides, hydroxides, and oxide minerals", In Aquatic Surface Chemistry (ed. W. Stumm), John Wiley \& Sons, pp. 83-110, 1987.
[4] Sukla L.B., Das R.P., "Kinetics of nickel dissolution from roasted laterites", Trans. Indian Inst. Met. vol. 40, pp. 351353,1987

[5] Mohapatra S., Pradhan N., Mohanty S., Sukla L.B., "Recovery of nickel from lateritic nickel ore using Aspergillus niger and optimization of parameters" Miner. Eng. vol. 22 pp. 311-313, 2009.

[6] Mohapatra S., Sengupta C., Nayak B.D., Sukla L.B., Mishra B.K., "Biological leaching of nickel and cobalt from lateritic nickel ore of Sukinda mines" Korean J. Chem. Eng. vol. 26, pp. 1-7, 2009.

[7] Mohapatra S., Bohidar S., Pradhan N., Kar R.N., Sukla L.B., "Microbial reduction of nickel from Sukinda chromite overburden by Acidithiobacillus Ferrooxidans and Aspergillus strains", Hydrometallurgy, vol. 85, pp. 1-8, 2007.

[8] Mohapatra S., Sengupta C., Nayak B.D., Sukla L.B., Mishra B.K., "Effect of thermal treatment on recovery of nickel and cobalt from Sukinda lateritic nickel ore using microorganism", Korean J. Chem. Eng. vol. 25, pp. 1070-1075, 2008.

[9] Xu M, Guo J, Kong X, Chen X, Sun G., "Fe(III)-enhanced Azo Reduction by Shewanella decolorationis" S12, Appl Microbiol Biotechnol., vol. 74, pp. 1342-1349, 2007.

[10] Eyers L., Stenuit B., Agathos S.N., "Denitration of 2,4,6-trinitrotoluene by Pseudomonas aeruginosa ESA-5 in the presence of ferrihy drite", App1 Microbiol Biotechnol. vol. 79 No.3, pp. 489-497, 2008.

[11] Wang B, Xu M, Sun G., "Comparative analysis of membranous proteomics of Shewanella decolorationis S12 grown with azo compound or Fe (III) citrate as sole terminal electron acceptor", Appl Microbiol Biotechnol. vol. 86, pp. 1513-1523, 2010 .

[12] Lovley D.R., "Dissimilatory metal reduction". Annual Rev. Microbiol. vol. 47, pp. 263-290, 1993.

[13] Bell P.E., Mills A.L. and Herman J.S., "Biogeochemical conditions favoring magnetite formation during anaerobic iron reduction", Appl. Environ. Microbiol. vol. 53, pp. 2610-2616, 1987.

[14] Lovley D.R., "Dissimilatory Fe (III) and Mn (IV) reduction", Microbiol Reviews vol. 55, pp. 259-287, 1991.

[15] Emmerich M., Bhansali A., Lösekann-Behrens T., Schröder C., Kappler A. and Behrens S. "Abundance, Distribution, and Activity of $\mathrm{Fe}(\mathrm{II})$-Oxidizing and $\mathrm{Fe}(\mathrm{III})$-Reducing Microorganisms in Hypersaline Sediments of Lake Kasin, Southern Russia", Appl. Environ. Microbiol. vol. 78, pp. 4386-4399, 2012

[16] Cho E.J. and Andrew D.E., "Optimization of the biological component of a bioelectrochemical cell", Bioelectrochemistry, vol. 70, pp.165-172, 2007.

[17] Kim S.J., Park S.J., Oh Y.S., Lee S.A., Shin K. S., Roh D.H., Rhee S.K. Shewanella arctica sp. nov., an iron-reducing bacterium isolated from Arctic marine sediment. Int J Syst. Evol. Microbiol. Vol. 62, pp. 1128-33, 2012.

[18] ValixM and Cheung W.H., "Study of phase transformation of laterite ores at high temperature", Minerals Engineering. vol. 15, pp. 607-612, 2002.

[19] Jinhui L., Xinhai L., Qiyang H., Zhixing W., Youyuan Z., 
Junchao Z., Wanrong L. and Lingjun L., "Effect of preroasting on leaching of laterite", Hydrometallurgy. vol. 99, pp. 84-88, 2009.

[20] Vogel A.I., "Text Book of Quantitative Inorganic Analysis Including Elementary Instrumental Analysis", third ed. ELBS \& London, London, pp. 310, 1961.

[21] Hansel C.M., 2004, PhD Thesis: Bacterial and geochemical controls on the reductive dissolution and secondary mineralization of iron (hydr)oxides. Department of geological and environmental sciences, Stanford University.
[22] Shmuel Y, Efraim M and Rafael V, Thermal transformation of goethite into hematite in alkali halide discs, J. Chem. Soc., Faraday Trans. vol. 76, pp. 1442-1454, 1980.

[23] Zener C, "Interaction between the * $\mathrm{d}^{*}$-Shells in the Transition Metals. II. Ferromagnetic Compounds of Manganese with Perovskite Structure", Phys. Rev. vol. 82, pp. 403-405, 1951

[24] Zener C, "Interaction Between the * $\mathrm{d} *$ Shells in the Transition Metals", Phys. Rev. vol. 81, pp. 440-444, 1951 